\title{
PRICKLE1 Gene
}

National Cancer Institute

\section{Source}

National Cancer Institute. PRICKLE1 Gene. NCI Thesaurus. Code C126758.

This gene is involved in gastrulation and the regulation of Wnt signaling. 